\title{
People's Negotiation of Space in the context of Urbanization and Historic Conservation in Clan Jetties, Malaysia
}

\author{
Kaushalya Herath \\ Transport and Logistics Management, \\ Faculty of Engineering University of Moratuwa, \\ Katubedda, Moratuwa, Sri Lanka \\ hkaushalya89@gmail.com
}

\begin{abstract}
Penang is a rapidly urbanizing city in Malaysia. Neo liberal urban development in Penang challenges the vernacular built environment of the city. The urban fabric of Penang is rich with different traits of architecture from the West and the East. With the population density and the land values going up, much of the local urban spaces are being replaced by the "modern" high rises and other land uses. While the colonial legacy of Penang built environment has been recognized by the heritage discourse to be conserved, self-built and local spaces are being ignored. Both urbanization and historic conservation impacts the transformation of Penang. In this context, Clan Jetties of Penang as a self-built settlement which was produced and transformed by ordinary people over the last century is facing the challenges of both urbanization and historic conservation.

This paper elaborates on how the Clan Jetty residents negotiate the spaces in the context of urbanization in order to survive and maintain their sense of belongings to their neighborhood. UNESCO incorporated Clan Jetties to the Georgetown World Heritage site in 2008. Although this new designation of world Heritage saved Clan Jetties from getting replaced, it also halted the natural transformation process of the settlement. However, people desire modernization to transform their neighborhood despite the heritage guidelines imposed upon them. Clan Jetty residents who rejected the conversion of their neighborhood to a "modern" neighborhood as defined and designed by the Government are in the process of following their own instincts in making small changes in their neighborhood. This paper discusses this continuous process of production of spaces by ordinary people by analyzing and contextualizing their stories.
\end{abstract}

Keywords: Urbanization, High-rise development, Agency, Socio-Cultural Changes, Transformation, Historic conservation, People's spaces. 


\section{Introduction}

Clan Jetties is a self-built settlement by Chinese immigrants in Penang, Malaysia. Some Chinese immigrants who came to what is now known as Malaysia looking for opportunities in the late $19^{\text {th }}$ and early $20^{\text {th }}$ centuries built livelihoods related to the activities of the Penang harbor. Penang is a key port on the sea routes and the gateway to northern Malaysia and the southern provinces of Thailand. Penang harbor operated as a free port ever since the British established it in 1786. This attracted labor, especially Chinese immigrants; some of whom owned boats and others worked as laborers in loading and unloading goods from the ships anchored in the deep areas of the ocean and bringing them to the shore and vice versa on dingies. Serving these boats, on the shore, were several jetties of different lengths. These jetties were used to anchor the boats that were used to shuttle break-bulk cargo and passengers between the land and the ship anchored in the deep ocean. Functionality of the port required both private boats and labor to handle the break- bulk at the Penang port, which was one of the busiest ports in the region.

Chinese immigrants who began to work in the labor-intensive port operations settled somewhere close to the harbor. Chew Yong $\mathrm{Fu}$ mentioned that Chinese immigrants who worked in loading and unloading boats were mostly single men at the beginning of the $20^{\text {th }}$ century. Eventually, some men got married to Malaysian women and others brought wives from China. These immigrant families who did not own land in Penang settled along Lebuh Acheh and Armenian Street. Those who had to wait by the jetties, i.e., until a ship arrives, built shelters along the side of the jetty where boats did not dock. As they did not want to miss a ship, single men decided to stay permanently at these shelters. Later, married men also brought their families to the jetties and constructed their houses on stilts, over the ocean, along the jetty. Eventually, this settlement grew into a community with a sense of belonging to its residents.

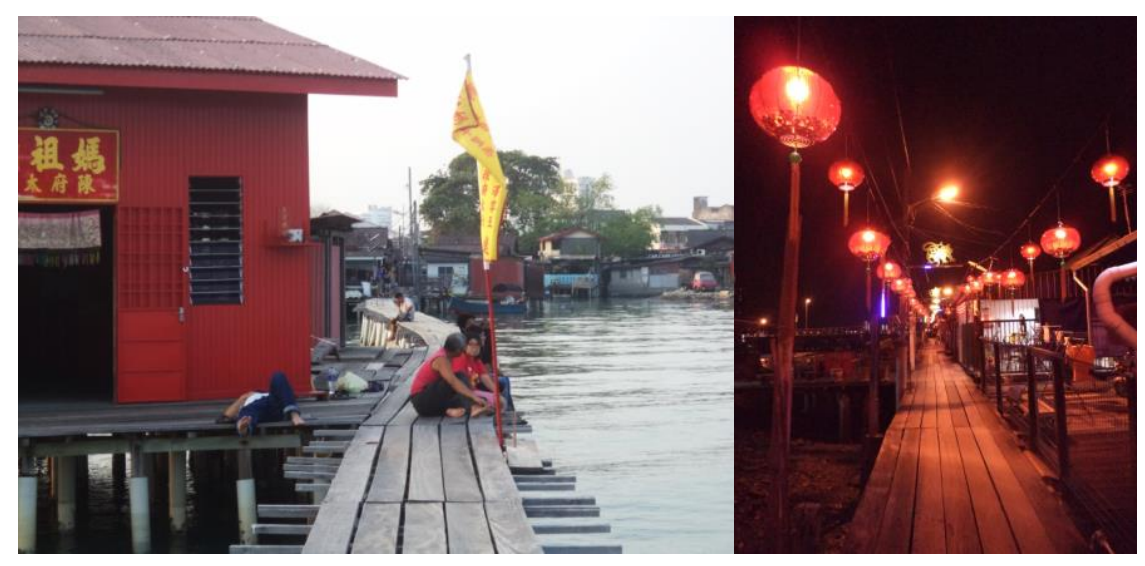

Fig. 1: Jetties at daytime and night time

Source: Author 
Later, with the transformations of the shipping industry and port operations, labor requirement of the port drastically reduced, causing most of the jetty dwellers to lose their jobs. The high unemployment rate, poor income and the population growth of the community took away the glory of the neighborhood. Sam Lim highlights that, in 1980s and 90s, outsiders and the Penang government began to view the Clan Jetty neighborhood as a "slum" or "unauthorized settlement." With the urbanization trends of Penang, the government made several attempts to demolish the neighborhood, build a high rise apartment complex and resettle Jetty dwellers.

Turning the tide, after some negotiations and random decisions, the Clan Jetties was included in the George Town World Heritage Site in 2008. The jetty residents were allowed to live in the neighborhood, but according to the world heritage guidelines and regulations. This paper discusses the displacement of Jetty residents in their own homes (Perera, 2015), how Jetty residents use their agency to negotiate the spaces, and how they are using new opportunities created by the world heritage designation. Main purpose of this research is to develop knowledge on people's process of production of places. This will also elaborate the need for professionals to pay close attention to people's agency regarding their own places instead of planning and building for them.

\section{Methodology}

Cities and neighborhoods are often understood from outside-in perspectives. This view of planners and other professionals 'other' the people in the community and limit the vision to what professionals already know about the community. Hence, understanding cities and settlements from within is important for people-friendly planning (Perera, 2015). Here people refer to those subjects who do not have the power to produce abstract spaces as the state and capital (Perera, 2015). This paper employs an inside-out perspective.

Ethnographic study for the research was conducted during an eleven week field study in 2015. Both field data, particularly people's stories and the secondary information were gathered from institutions in Penang, and existing literature are used to understand the transformation. The key methods employed to collect field data were observations, participant observation, and unstructured interviews.

Researchers have their own stereotypes and it is inevitable that they add subjectivity to the study and findings. Therefore, this study is not free from researcher's subjective understanding and some of the pre-conceptions. In order to acknowledge that, instead of making the researcher a third person or an outsider, this paper acknowledges the subjectivity of the researcher and reflects on the personal experience, expanding the areas that the researcher could reach. Thus it is narrated in first person.

I lived near the Clan Jetties and visited it almost every day, some days from early mornings until midnight. I was accompanied by my colleagues from the university with whom I made informal connections with Jetty residents and began casual conversations. Through these conversations, we became their family friends. Instead of administering a questionnaire full of pre-conceptions, I learned about the community beginning from people's everyday stories. This method of learning is similar to the 
'science of muddling through' (Lindblom,1959), but was consciously adopted. Following the branch method, as well as the snowballing method. Instead of pushing for knowledge that I wished to gain, I let the knowledge accumulate as it came. This method allows the researcher to explore into new areas of knowledge instead of juggling within the already known knowledge framework.

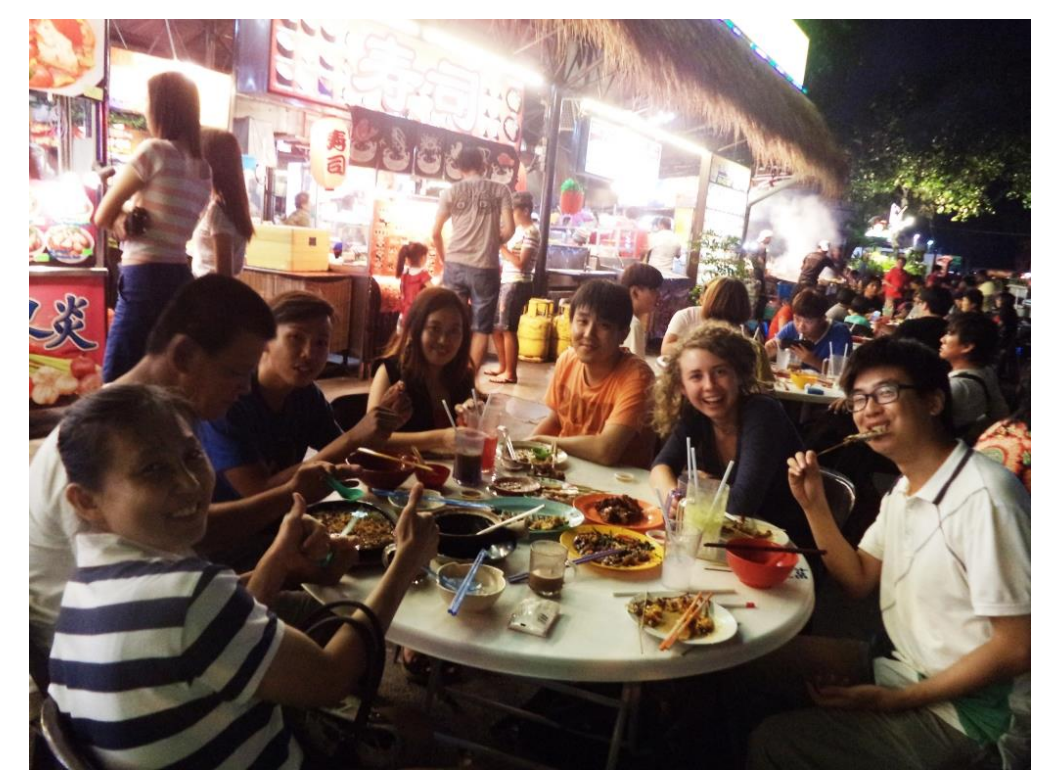

Fig. 2: Dinner with some Jetty Residents

Source: Author

From the third week, I organized and thermalized the stories and expanded the investigation into areas that were needed for better understanding of the community. I also verified the initial stories through the consultation of other residents and expanded on the themes. I collected formal literature and historic data on the port operations from institutions in Penang. At the writing stage, I combined these stories to develop the larger story focusing on how people use their agency to negotiate spaces of modernization and change transport infrastructure by coping, resisting and altering both their lives and spaces imposed by external agencies.

\section{Production of spaces by people}

David Harvey (1973) argues that space is a social relation. They are more than physical entities and ordinary people give meanings to them. Perera (2015) demonstrates that the state is not the sole producer of the space, but ordinary people also create new spaces out of their requirements and desires. Clan Jetties settlement was produced by a marginalized group of people who did not own land in the city. They did not have access to lands closer to their workplace; the accessible lands were far away from them. Yet the nature of their work did not support commuting from home. 
Therefore, they brought their homes to work, i.e., they produced a settlement at their workplace, merging the production and reproduction processes.

This changed the urban morphology of Penang. The immigrants not only produced a new settlement but also added a new liveable area to the city, without even reclaiming the ocean. This neighborhood of houses built on the stilts over the ocean added a new identity to the urban area. Clan Jetty residents gave a new meaning to Penang by changing the urban form, adding more land area, creating a new appearance and functioning as an essential part of the economy by complementing the port operations. Clan Jetties became a land use support system to the port operations. As Penang's history is strongly linked to the harbor, the Clan Jetties is an important part of the urbanization of Penang.

The process of production of spaces by ordinary people is a complex negotiation that involves culture, gender, natural factors, local economy, and other external factors such as state development policies, modernization, urbanization, and transportation. The production of Clan Jetties provides insights into the above factors and larger negotiations.

The Chinese immigrants occupied jetties according to their family names and these group were called clans. Only the "clansmen" from the relevant clan could join a particular Jetty; the same process applied to building houses along a jetty. Today, there are seven Jetties that belong to six clans; one is a mixed jetty that was recently built by the government to accommodate jetty-residents who were displaced due to a road widening project.

As people came to live in these jetties, they also built temples and shrines for their particular deities, thus adding special identities to each neighborhood. They also added spaces to play majiang and for other types of socialization. This sense of place was expanded by activities such as commerce.

Although this transformation happens locally, it is inspired from various other places and affects other places. Some jetty residents still believe in a very strong connection to their native villages in China. They bring house ornaments, statues of Gods and other religious decorations from Fujian Province, their homeland. Some of them have relatives who live in Hong-Kong, Singapore or other parts of Malaysia, so they borrow trends from the other places and negotiate them according to the requirement, desires and culture they have in Clan Jetties. Clan members influence their foreign relatives too. 


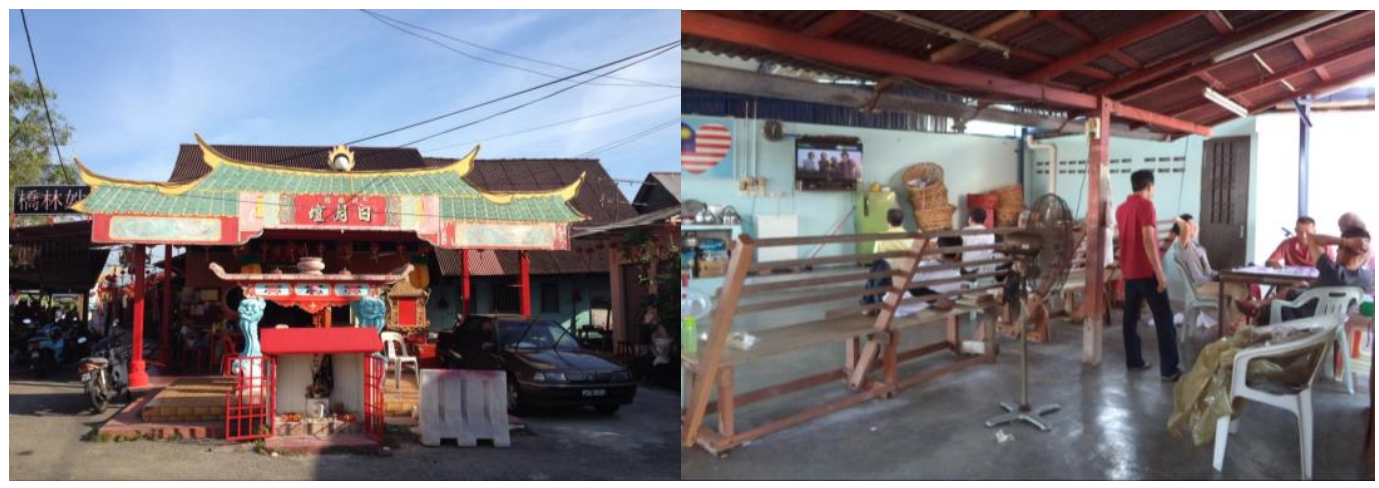

Fig. 3: Lim Jetty Temple

Fig. 4: Chew Jetty Community Space Source: Author

\section{Survival of the community in the midst of changing port operations}

The second phase of Clan Jetty history is connected to the shift of port operations from labor-intensive break-bulk-handling operations to technologically advanced container terminals. This switch suddenly dropped the demand for semiskilled and unskilled labor for port operations. Clan Jetty residents in general lost their livelihoods. As stated in the Penang Port Website, Penang port constructed a container terminal in 1974 and currently the passengers arrive at the Swettenham Pier Cruise Terminal and in 2010, the jetties were abandoned. Then, the residents built houses on the other side of the jetties, accommodating the population growth. The boats that were anchored on the other side of the Jetties eventually disappeared.

With the above change, the once-wealthy residents in the jetties were unable to afford the maintenance of their houses built on stilts. Houses became dilapidated and some residents began utilizing the strategic location of the jetties right by the harbor for undefined "illegal activities". The area eventually became notorious for crimes and smuggling. Less-maintained houses had increasingly polluted the ocean, making the area unhygienic. Alex Koenig, a German researcher who has worked in Penang for over three decades, mentioned that when he first arrived in Penang, everybody he knew in the town advised him not to go to Clan Jetties due to health and safety concerns. The Penang government made several attempts to tear down the settlement and reclaim the seafront to build high-rise apartments to match the thriving port and neoliberal urban development in Penang.

Da Lim who runs a Majiang place where the Lim Jetty meets the shore said that he moved out from the Jetties in the mid-1980s "because it (Clan Jetties) was a slum", and not a good place for his kids to grow up. Neil Tang said his parents bought a house in a newly built apartment complex in another part of the city because the government made few announcements of tearing down the Clan Jetties. They kept their houses on the jetty although they bought a house in a place where they thought the living standards were high. Despite the out-migration of younger generation looking for jobs and better living standards as they defined, many families stayed and are not willing to give up their neighborhood. 


\section{Impacts of Urbanization on Clan Jetties and residents}

Pulau Pinang (Penang Island), Malaysia is a rapidly urbanizing city of the region. Penang state has one of the highest population densities in Malaysia (Statistics Department, 2010), Pinang state has 1490 persons per square Kilo Meter. It has the third highest growth rate of urban population at 91.4\%. Rapid Urbanization and government policies for urban development have caused the trend of building high-rise buildings in the city. Referring to Penang, Ryoko Sakurada (2012) writes, "Modernization seems to penetrate into every corner of the society. The rapid boom of constructing prefabricated houses and high-rising apartments makes landscapes of cities quite conventional and tasteless".

According to Sakurada (2012), "house ownership became one of the main objectives of the New Economic Policy (NEP) during 1971 to 1990" in Malaysia under the social objective of "home owning democracy". Clan Jetty residents refused to live in "government-oriented living environments" (Sakurada, 2012) that are low-cost apartments in high-rise buildings provided through the governmentally subsidized lowcost housing estates.

With the densification of the urban fabric and the sprouting of high-rise buildings in Penang, Clan Jetties looked different. This different character of the settlement was viewed as challenging to the neoliberal urbanization of the local government. Clan Jetties were thus considered 'Slums'. Clan Jetty residents demanded that they want to live in their own neighborhood because this is a neighborhood that they built and transformed. They have a strong sense of belonging to the community.

\section{Were the voices of people heard?}

It was both a blessing and a curse that, in 2008, Clan Jetties was included in the George Town world heritage site. It survived; its residents were allowed to live in their own houses.

A researcher in Penang said that there were hidden agendas behind the government's attempt to take over the clan jetties and reclaim the sea to build a high rise apartment complex. It would be owned by the government which is Malaydominated. This act followed the political agenda of the nationalistic government which favored the land ownership of Bhumi Puthras (Sons of the Land), the Malays. This vision was proclaimed by Mahathir Mohamad (1970) who as the fourth Prime Minister carried out the rapid modernization and urbanization of Malaysia and established the rights of the Malays.

Penang's Local Authority claimed that Clan Jetty Residents only have Temporary Occupant License (TOL). They only own their houses, not the land. The majority land owning Chinese Malaysians in the city were not happy with the government's decision to take over the Jetties settlement because then the land will be owned by the Malay government. They were able to fight against the government's decision due to their privileged position and access to the power structure in Penang. 
Lim Gaik Siang, the president of Penang Heritage Trust Council, stated "we played a major role in including Clan Jetties when declaring George Town World Heritage Site". This was a very strong statement to claim that they acted as the mediator between "people" and the government.

Ordinary people's voices were not heard in the process of becoming a world heritage. Yet the powerful land-owning Chinese with a political power could make them heard by the government and influenced the policy decision. Clan Jetty residents were also not passive subjects in this. They reached out to these powerful Chinese Malaysians in order to get what they want. Political and power contestation between Chinese Malaysians and the government proved to be advantageous.

\section{Becoming a world heritage and thereafter}

Today, Clan Jetty residents have to live according to the guidelines and regulations from the government. UNESCO world heritage site regulations and guidelines are introduced to the Clan Jetties. Mostly, these regulations are to maintain the façade and the roof unchanged. Residents have to get the permission to do any repairs to their houses. According to the Special Area Plan for George Town world heritage site (2011), following works require repair permits.

"Repair and maintenance work such as plumbing, fixing roof, leakage, and re-wiring works; re-roofing of a building or any parts of a building; re-plastering and/or repainting of part of a building; putting back original materials that are missing from front façade and roof; change of material for any part of the building; clearing works related to burnt/ dilapidated building, either partly or fully and/or removal of overgrown plants; and installation of temporary protective/ safety measure or fencing/hoarding on buildings/sites".

Special Area Plan for George Town world heritage site (2011)

In short, as Perera (2015) highlights in regard to the residents in the Galle Fort, Jetty residents too are 'displaced in their own homes'.

However, Clan Jetty residents use their agency in order to survive and thrive in the new context imposed upon them. Chew Jetty where the Chews live as a group, is the most populated jetty and the one visited by most tourists. Tourism can be a nuisance at times, its residents have restricted the time of the day that tourists are allowed on the jetties, thus claiming the neighborhood for the residents during nighttime. Some residents have put up signs displaying 'no photographs' and 'no entry' at their premises because some tourists do not understand that these are private houses and the residents have privacy and safety concerns.

Janice Khaw, a newly wedded woman in the New Jetty said that some tourists even try to come inside their houses and take pictures. As she was new to jetties and originally from a gated residential neighborhood in Penang, she did not like this crowded neighborhood with tourists glimpsing into their houses. Most of the houses in the jetty had a wooden front door and also a screen door. Da Ben Mao said that they 
keep the wooden door open and the screen door closed during the daytime to get the ventilation while keeping the tourists out.

Clan Jetty residents use the exceptions of rules to make the settlement livable for them. As Partha Chatterjee argues exceptions are as important as the rule to understand the rule. Rules can exist because exceptions that provide space to survive for people who would otherwise break the rule (cited in Perera, 2015). UNESCO world heritage has enacted strict regulations on protecting the façade and the roof of houses. People have figured out ways to achieve their modernization desires by changing the interior. Some houses are like modern units covered with an old face and a headdress.

Chew Jetty Café owner has two houses on the Jetty. The backside of one of his houses connect to the land and he has made the back entrance to a 'modern' façade. He keeps the front of his house according to the world heritage guidelines. Da Ben Mao said his father extended the back of the house three times in last ten years. Although there is no sewage system and all sewerage is directly dumped into the ocean, residents are converting their pit latrines to water-sealed toilets with seats. Some houses are air conditioned and equipped with modern accessories. They are changing the floors from wooden materials to concrete floors. An officer from the UNESCO world heritage office said, "we also have noticed that people are changing the floor materials but we do not want to act on it and make it more difficult for people to live in their own houses". This understanding of local officers that the rules will not work if they are too tight and restrict people's agency entirely is important in keeping the livability of the neighborhood. Yet they have not provided any means to discharge the sewage and dispose the garbage

Clan Jetty residents are using the opportunities of tourism to get economic benefits. Some of the younger people who left jetties are coming back to Jetties. Henry Chew said he lives with his parents who left the Jetty to live in a wealthy area of Penang and he came back to begin a souvenir shop at his grandparents' home in Chew Jetty.

Some Jetty residents who are employed elsewhere have also opened part time shops, so they can grab the opportunity of flowing tourists and make maximum use out of it. Chew Guo Hua is a shrimp breeder who runs a souvenir shop only during the afternoon when he gets some free time. Jetty residents are using their agency to make use of blind spots of the rules to maximize the newly created opportunities. Although the heritage rules are trying to preserve the history at one point, Clan Jetties residents are transforming their community in slight ways. 


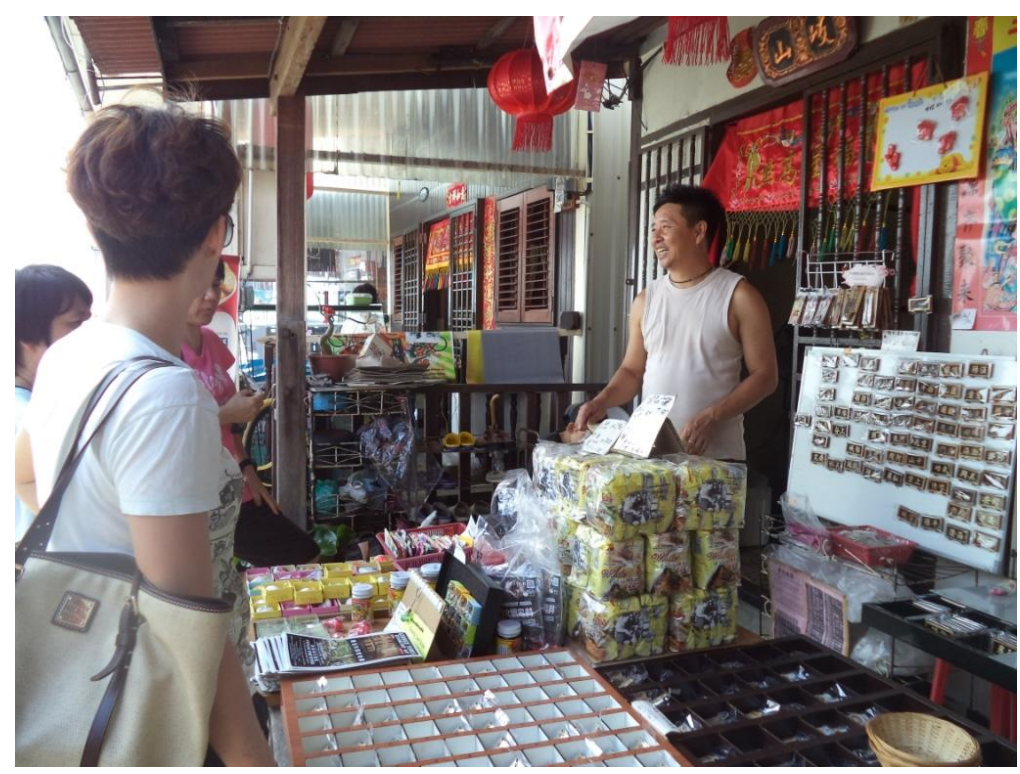

Fig.4: Chew Guo Hua with his customers Source: Author

Clan Jetties settlement which was a self-built neighborhood not only produced a land use or provided a new meaning to space, but also added some land area to the Penang island without reclaiming the ocean but by constructing their houses over the sea. These houses served an important purpose of the city. As a city associated with a harbor and the development of the city was induced by the port, Clan jetties was a product of the port's operations, serving as a labor pool for it.

This self-built neighborhood was in the continuous process of transformation as the modernization desires of people were growing. Clan Jetty residents keep blending their original culture with the one in Penang and other trends from outside. This 'translocality' (Appadurai, 1996) which was in a live transition with a unique architectural and cultural addition to the urban fabric of Penang was seen as mismatching for the neo-liberal, modern urban development associated with the lowincome housing policies and high rise building culture in Penang. Clan Jetties survived in the midst of grand urbanization due to the unlimited courage of locals, support of powerful groups and the popular heritage discourses.

Naming a world heritage site assured the existence of the physical entity of Jetties, but restricted the process that produced and transformed Jetties. Although the Jetties are declared a world heritage site, Clan Jetty residents have found ways to keep it alive, growing and modernizing. This agency of people in producing and transforming spaces even when the process is regulated, is worth exploring in the planning process and development.

\section{Conclusion}

People negotiate spaces every day. Clan Jetty Residents produced their neighborhood and transformed it over the last century. They have faced different challenges over the last century such as conversion of Penang port to a containerized port from a labor-intensive port, neo liberal urban development, government housing 
policies, and incorporation into world heritage site. Clan Jetty residents had their own ways to negotiate each of these socio-economic changes related to their spaces. Most of the professionals lack the knowledge about these day-to-day negotiations and spaces people produce in order to make their neighborhood friendly for them. This paper highlights the people's space making process in Clan Jetties while it does not generalize the findings to all the other settlements. Production of spaces and how people use their agency is unique in every settlement. It depends on many socio-cultural attributes. Professionals with technical and theoretical knowledge should not overlook the ordinary people's contribution in the process of making better places for themselves.

Clan Jetties, which is a neighborhood that outsiders viewed as an unhygienic and unsafe 'slum' is a home with a strong sense of belongings to its people. Clan Jetties settlement elaborates that when people produce their spaces and have the ability to transform them with their ever changing modernizing needs, people have a strong sense of belongings over the neighborhood compared to spaces given to them. Without understanding the spaces people produce and the values they incorporate in the process, professionals or the government cannot produce inclusive spaces.

The story of Clan Jetties highlights that people negotiate spaces even in the midst of very powerful discourses such as urbanization and historic conservation. Therefore, it is wise to study ground level processes in the production of spaces in planning and building for people.

\section{Reference}

Appadurai, A. (1996) Modernity at Large: Cultural dimensions of globalization, Minneapolis,MN: University of Minnesota Press.

Department of Statistics Malaysia official portal, Viewed 6/30/2017, https://www.dosm.gov.my/v1/

Lindblom, C. (1959), The Science of Muddling Through, Public Administration

Review, 19(2), 79-88

Mohamad, M. (1970) Malay Dilemma, Singapore: Asia Pacific Press

Penang port website, Viewed 24.04.2017, www.penangport.com.my

Perera, N. (2015) People's spaces: Coping, Familiarizing, Creating. London and New York: Routledge.

Sakurada, R. (2012) 'Modernity and Anthropology: Housing Estate, Media, and Consumption of Tradition', The Reports of the Intensive Social Research Program on Chinese Society of Kyoto Erasmus Project. pp 4-19 